\title{
PERANKINGAN PROPORSI PENGANGGURAN TERBUKA SETIAP KABUPATEN/KOTA DI PROPINSI SUMATERA BARAT TAHUN 2013 DENGAN METODE BAYES
}

\author{
TIARA SHOFI EDRIANI, DODI DEVIANTO, HAZMIRA YOZZA \\ Program Studi Matematika, \\ Fakultas Matematika dan Ilmu Pengetahuan Alam, Universitas Andalas, \\ Kampus UNAND Limau Manis Padang, Indonesia. \\ email : tiarashofiedriani@gmail.com
}

\begin{abstract}
Abstrak. Perankingan merupakan upaya mengurutkan suatu nilai dari nilai terkecil hingga terbesar atau sebaliknya. Nilai yang diurutkan tersebut merupakan hasil pendugaan parameter populasi seperti nilai tengah, ragam, proporsi dan lain-lain. Pada penelitian ini dilakukan perankingan pengangguran terbuka di Provinsi Sumatera Barat tahun 2013 berdasarkan hasil pendugaan parameter proporsi masing-masing kabupaten/kota dengan menggunakan metode Bayes. Proporsi pengangguran terbuka dianggap sebagai parameter $\theta$ dari data yang berdistribusi Binomial. Ranking menunjukkan tinggi rendahnya selang nilai penduga proporsi pada setiap kabupaten/kota berdasarkan iterasi yang dilakukan dengan menggunakan metode Gibbs Sampling terhadap nilai tengah fungsi kepekatan peluang distribusi posterior masing-masing parameter proporsi.

Kata Kunci: Ranking, Pengangguran Terbuka, Distribusi Binomial, Metode Bayes, WinBugs, Gibbs Sampling
\end{abstract}

\section{Pendahuluan}

Dalam bidang kependudukan dan ketenagakerjaan terdapat penduduk usia kerja (15 tahun ke atas) yang bekerja atau punya pekerjaan namun sementara tidak bekerja dan pengangguran yang disebut angkatan kerja. Pengangguran terbuka merupakan bagian dari angkatan kerja yaitu mereka yang tidak punya pekerjaan dan mencari pekerjaan, mereka yang tidak punya pekerjaan dan memepersiapkan usaha, mereka yang tidak punya pekerjaan dan tidak mencari pekerjaan karena merasa tidak mungkin mendapatkan pekerjaan serta mereka yang sudah punya pekerjaan tetapi belum mulai bekerja [3].

Proporsi pengangguran terbuka menunjukkan keadaan bidang kependudukan dan ketenagakerjaan sehingga dapat diperoleh gambaran pemusatan pengangguran terbuka di suatu wilayah. Proporsi merupakan parameter yang tidak diketahui nilainya secara keseluruhan. Oleh sebab itu perlu dilakukan prosedur untuk menduga parameter proporsi yang disebut pendugaan parameter. Pendugaan parameter meliputi pendugaan titik dan pendugaan selang. Metode yang digunakan dalam pendugaan parameter adalah metode klasik dan metode Bayes. Metode klasik semata-mata mengandalkan informasi yang diperoleh dari sampel acak yang ditarik 
dari populasi untuk menduga parameter. Metode Bayes memandang parameter sebagai variabel acak yang menggambarkan pengetahuan awal tentang parameter sebelum pengamatan dilakukan dan dinyatakan dalam sebuah distribusi yaitu distribusi prior [5]. Kemudian, data sampel akan dikombinasikan dengan informasi dalam distribusi prior melalui teorema Bayes dan hasil pendugaan parameter dinyatakan dalam bentuk distribusi yang disebut distribusi posterior.

Dalam penelitian ini dibahas bagaimana menentukan ranking pengangguran terbuka di Provinsi Sumatera Barat tahun 2013 berdasarkan hasil pendugaan parameter proporsi masing-masing kabupaten/kota dengan menggunakan metode Bayes. Proporsi pengangguran terbuka di Sumatera Barat tahun 2013 dianggap sebagai parameter $\theta$ dari data pengangguran terbuka yang berdistribusi Binomial.

\section{Pendugaan Parameter $\theta$ pada Distribusi Binomial dengan Metode Bayes}

Metode Bayes adalah metode pendugaan parameter yang berdasar kepada teorema Bayes. Parameter yang diduga dengan metode Bayes merupakan peubah acak yang mempunyai distribusi tertentu. Metode Bayes menggabungkan fungsi likelihood dari data dan distribusi Prior dari parameter untuk mendapatkan distribusi Posterior. Dalam penelitian ini dilakukan pendugaan parameter $\theta$ pada distribusi $\operatorname{Binomial}(1, \theta)$ dengan metode Bayes.

Salah satu distribusi dari peubah acak diskret adalah distribusi binomial. Peubah acak binomial didefinisikan sebagai banyaknya keberhasilan yang muncul dari ulangan-ulangan Bernoulli yang saling bebas. Ulangan Bernoulli merupakan sebuah ulangan percobaan yang hanya memiliki dua hasil, berhasil atau gagal.

Distribusi binomial adalah distribusi peluang bagi peubah acak Binomial $X$ dimana setiap ulangan Binomial mempunyai peluang keberhasilan $\theta$ dan peluang kegagalan $1-\theta$. Fungsi kepekatan peluang dari distribusi binomial adalah

$$
b(x ; n, \theta)=\left(\begin{array}{l}
n \\
x
\end{array}\right) \theta^{x}(1-\theta)^{n-x} \text { untuk } x=0,1,2, \cdots, n
$$

Kemudian ditentukan fungsi likelihood dari data. Fungsi kepekatan peluang bersama dari $X_{1}, X_{2}, \cdots, X_{n}$ yang dihitung pada $x_{1}, x_{2}, \cdots, x_{n}$ adalah $f\left(x_{1}, x_{2}, \cdots, x_{n} ; \theta\right)$ dan ini dirujuk oleh fungsi likelihood. Untuk $x_{1}, x_{2}, \cdots, x_{n}$ tetap, fungsi likelihood adalah fungsi dari $\theta$ dan dinotasikan $L(\theta)$. Jika $X_{1}, X_{2}, \cdots, X_{n}$ sampai acak dari $f(x ; \theta)$ yang berdistribusi binomial maka

$$
L(\theta)=\prod_{i=1}^{n} f\left(x_{i} ; \theta\right)=\prod_{i=1}^{n}\left(\begin{array}{c}
1 \\
x_{i}
\end{array}\right) \theta^{x_{i}}(1-\theta)^{1-x_{i}}=\theta^{\sum_{i=1}^{n} x_{i}}(1-\theta)^{n-\sum_{i=1}^{n} x_{i}} .
$$

Proporsi $\theta$ merupakan parameter populasi dengan selang nilai 0 sampai 1 . Dalam pendugaan parameter menggunakan metode Bayes, diperlukan distribusi awal yang memberikan informasi mengenai parameter yang disebut distribusi prior. Pada dasarnya, distribusi prior adalah representasi subjektif peneliti terhadap suatu nilai parameter yang diduga.

Distribusi prior yang berkaitan dengan bentuk distribusi hasil identifikasi pola datanya dikelompokkan menjadi distribusi prior konjugat dan distribusi prior tidak konjugat. Distribusi prior konjugat mengacu pada acuan analisis model terutama 
dalam pembentukan fungsi likelihoodnya sehingga dalam penentuan prior konjugat selalu dipikirkan mengenai pembentukan pola distribusi prior yang mempunyai fungsi kepekatan peluang pembangun likelihoodnya. Apabila pemberian prior pada suatu model tidak mengindahkan pola pembentuk fungsi likelihoodnya disebut dengan distribusi prior tidak konjugat [6].

Berdasarkan penentu parameter pada pola distribusinya, distribusi prior dikelompokkan menjadi distribusi prior informatif dan distribusi prior noninformatif. Distribusi prior informatif mengacu pada pemberian parameter dari distribusi prior yang telah dipilih, baik distribusi prior konjugat atau tidak. Pemberian nilai parameter pada distribusi prior ini akan sangat mempengaruhi bentuk distribusi posterior yang akan didapat pada informasi data yang diperoleh. Pada distribusi prior non-informatif, informasi mengenai parameter tidak tersedia, pemilihannya tidak didasarkan pada data yang ada atau distribusi priornya tidak mengandung informasi tentang parameter [6].

Selanjutnya, informasi distribusi prior digabungkan dengan informasi dari data melalui teorema Bayes sehingga menghasilkan distribusi baru bagi $\theta$ yaitu distribusi posterior. Secara umum distribusi posterior dapat dinyatakan sebagai fungsi kepekatan peluang bersyarat dari $\theta$ jika diketahui nilai observasi $x$, misalkan $\mathbf{x}=\left(x_{1}, x_{2}, \cdots, x_{n}\right)$, dapat ditulis

$$
f(\theta \mid \mathbf{x})=\frac{f(\theta, \mathbf{x})}{f(\mathbf{x})}
$$

Fungsi kepekatan peluang bersama dari contoh acak dan parameter $\theta$ yang dinyatakan dalam bentuk fungsi likelihood dan distribusi prior. Dalam pendugaan proporsi pengangguran terbuka setiap kabupaten/kota di Provinsi Sumatera Barat tahun 2013 dengan metode Bayes, diasumsikan distribusi prior yang digunakan adalah distribusi Beta(1,1) sehingga dapat ditulis

$$
f(\theta, \mathbf{x})=f(\mathbf{x} \mid \theta) f(\theta)=\theta^{\sum_{i=1}^{n} x_{i}}(1-\theta)^{n-\sum_{i=1}^{n} x_{i}},
$$

dimana $f(\mathbf{x} \mid \theta)$ menyatakan fungsi likelihood dan $f(\theta)$ menyatakan fungsi kepekatan peluang prior bagi $\theta$. Selanjutnya fungsi kepekatan peluang marginal dari contoh acak dapat dinyatakan sebagai

$$
\begin{aligned}
f(\mathbf{x}) & =\int_{-\infty}^{\infty} f(\theta, \mathbf{x}) d \theta=\int_{-\infty}^{\infty} f(\theta) f(\mathbf{x} \mid \theta) d \theta \\
& =\int_{-\infty}^{\infty} \theta^{\sum_{i=1}^{n} x_{i}}(1-\theta)^{n-\sum_{i=1}^{n} x_{i}} d \theta=B(x+1, n-x+1) .
\end{aligned}
$$

Berdasarkan persamaan (2.1), (2.2) dan (2.3), fungsi kepekatan peluang distribusi posterior dapat didefinisikan dengan

$$
\begin{aligned}
f(\theta \mid \mathbf{x}) & =\frac{f(\mathbf{x} \mid \theta) f(\theta)}{\int_{-\infty}^{\infty} f(\mathbf{x} \mid \theta) f(\theta) d \theta}=\frac{\theta^{x}(1-\theta)^{n-x}}{B(x+1, n-x+1)} \\
& =\frac{1}{B(x+1, n-x+1)} \theta^{x+1-1}(1-\theta)^{n-x+1-1} .
\end{aligned}
$$


Distribusi posterior bagi $\theta$ adalah $B(x+1, n-x+1)$. Nilai tengah atau nilai ekspektasi distribusi posterior digunakan untuk menentukan nilai pendugaan titik Bayes bagi parameter $\theta$ yang tidak diketahui.

\section{Data dan Metode}

Penelitian ini menggunakan data sekunder dari Badan Pusat Statistik Provinsi Sumatera Barat yaitu data angkatan kerja setiap kabupaten/kota di Sumatera Barat tahun 2013.

Tabel 1. Penduduk Berumur 15 Tahun ke Atas yang Termasuk Angkatan Kerja di Kabupaten/Kota Provinsi Sumatera Barat Tahun 2013

\begin{tabular}{|c|c|c|c|c|c|}
\hline NO & Kabupaten/Kota & $\begin{array}{c}\text { Angkatan } \\
\text { Kerja }\end{array}$ & Bekerja & $\begin{array}{c}\text { Pengangguran } \\
\text { Terbuka }\end{array}$ & TPT (\%) \\
\hline 1 & Kepulauan Mentawai & 38054 & 37900 & 154 & 0.4 \\
\hline 2 & Kab. Pesisir Selatan & 168913 & 150225 & 18688 & 11.06 \\
\hline 3 & Kab. Solok & 144350 & 136099 & 8251 & 5.72 \\
\hline 4 & Kab. Sijunjung & 88470 & 85136 & 3334 & 3.77 \\
\hline 5 & Kab. Tanah Datar & 172722 & 164359 & 8363 & 4.84 \\
\hline 6 & Kab. Padang Pariaman & 162999 & 150923 & 12076 & 7.41 \\
\hline 7 & Kab. Agam & 199298 & 188416 & 10882 & 5.46 \\
\hline 8 & Kab. Limapuluh Kota & 175523 & 168685 & 6838 & 3.9 \\
\hline 9 & Kab. Pasaman & 124003 & 122095 & 1908 & 1.54 \\
\hline 10 & Kab. Solok Selatan & 61449 & 59234 & 2215 & 3.6 \\
\hline 11 & Kab. Dhamasraya & 97243 & 92254 & 4989 & 5.13 \\
\hline 12 & Kab. Pasaman Barat & 143726 & 134401 & 9325 & 6.49 \\
\hline 13 & Kota Padang & 361071 & 310566 & 50505 & 13.99 \\
\hline 14 & Kota Solok & 26473 & 24990 & 1483 & 5.6 \\
\hline 15 & Kota Sawahlunto & 27581 & 25882 & 1699 & 6.16 \\
\hline 16 & Kota Padang Panjang & 22034 & 20476 & 1558 & 7.07 \\
\hline 17 & Kota Bukittinggi & 51920 & 49492 & 2428 & 4.68 \\
\hline 18 & Kota Payakumbuh & 56024 & 52028 & 3996 & 7.13 \\
\hline 19 & Kota Pariaman & 34532 & 32464 & 2068 & 5.99 \\
\hline
\end{tabular}

Berdasarkan data tersebut dilakukan pendugaan parameter proporsi pengangguran terbuka setiap kabupaten/kota di Sumatera Barat dengan metode Bayes dengan diaplikasikan melalui software WinBugs. Asumsikan bahwa jumlah pengangguran terbuka di Sumatera Barat tahun 2013 berdistribusi Binomial dengan proporsinya dianggap sebagai parameter $\theta$. Lalu diasumsikan distribusi prior bagi parameter $\theta$ yaitu $\operatorname{Beta}(1,1)$ hingga diperoleh distribusi posterior.

Pada WinBugs, nilai parameter proporsi diduga dengan pendekatan Bayesian Markov Chain Monte Carlo (MCMC), yaitu pendekatan numerik untuk mendapatkan distribusi posterior khususnya jika distribusi posterior dari parameter yang diduga memiliki bentuk yang tidak standar dan rumit [7]. Salah satu metode MCMC untuk menduga proporsi pengangguran terbuka setiap kabupaten/kota adalah metode Gibbs Sampling dengan algoritma sebagai berikut

(1) Tentukan nilai awal $\theta^{(0)}$.

(2) Untuk iterasi $t=1,2, \cdots, T$ ulangi langkah-langkah berikut

- Atur $\theta=\theta^{(t-1)}$. 
- Untuk $j=1,2, \cdots, k$, bangkitkan $\theta_{j}$ dari distribusi posterior.

- Bangkitkan $\theta_{1}^{(t)}$ dari $f\left(\theta_{1} \mid \theta_{2}^{(t-1)}, \theta_{3}^{(t-1)}, \cdots, \theta_{k}^{(t-1)}, \mathbf{x}\right)$. Bangkitkan $\theta_{2}^{(t)}$ dari $f\left(\theta_{2} \mid \theta_{1}^{(t-1)}, \theta_{3}^{(t-1)}, \cdots, \theta_{k}^{(t-1)}, \mathbf{x}\right)$.

$$
\text { Bangkitkan } \theta_{k}^{(t)} \text { dari } f\left(\theta_{k} \mid \theta_{1}^{(t-1)}, \theta_{2}^{(t-1)}, \cdots, \theta_{k-1}^{(t-1)}, \mathbf{x}\right) .
$$

Pendugaan parameter Bayes menggunakan WinBugs dilakukan sebanyak iterasi yang diinginkan sehingga menghasilkan pendugaan yang lebih teliti, konvergen dalam suatu selang nilai dan mendekati nilai parameter yang sebenarnya.

Selanjutnya dilakukan perankingan pengangguran terbuka kabupaten/kota di Sumatera Barat tahun 2013 berdasarkan nilai penduga proporsinya. Nilai tersebut pada masing-masing kabupaten/kota diiterasi sebanyak 20.000 kali menggunakan software WinBugs sehingga menghasilkan nilai pendugaan proporsi dalam selang tertentu. Selang nilai duga masing-masing kabupaten/kota diurutkan dari nilai terkecil hingga terbesar sehingga membentuk ranking.

\section{Perankingan Proporsi Pengangguran Terbuka Setiap Kabupaten/Kota di Sumatera Barat Tahun 2013 dengan Metode Bayes}

Sebelum melakukan perankingan proporsi pengangguran terbuka dari data Tabel 1, terlebih dahulu ditentukan pendugaan proporsi dari data tersebut menggunakan software WinBugs dengan hasil sebagai berikut.

Tabel 2. Pendugaan Proporsi Pengangguran Terbuka di Sumatera Barat Tahun 2013

\begin{tabular}{|c|c|c|c|c|c|}
\hline$\hat{\theta}_{B}$ & $\begin{array}{c}\text { Nilai } \\
\text { Tingah }\end{array}$ & $\begin{array}{c}\text { Standar } \\
\text { Deviasi }\end{array}$ & $\begin{array}{c}\text { Batas Bawah } \\
2.5 \%\end{array}$ & Median & $\begin{array}{c}\text { Batas Atas } \\
97.5 \%\end{array}$ \\
\hline$\hat{\theta}_{B}(13)$ & 0.13999 & $5.736 \mathrm{E}-4$ & 0.1388 & 0.1399 & 0.141 \\
\hline$\hat{\theta}_{B}(2)$ & 0.1106 & $7.647 \mathrm{E}-4$ & 0.1091 & 0.1106 & 0.1121 \\
\hline$\hat{\theta}_{B}(6)$ & 0.07409 & $6.49 \mathrm{E}-4$ & 0.07282 & 0.07409 & 0.07537 \\
\hline$\hat{\theta}_{B}(18)$ & 0.07134 & 0.001089 & 0.0692 & 0.07133 & 0.07351 \\
\hline$\hat{\theta}_{B}(16)$ & 0.07074 & 0.001708 & 0.06745 & 0.07072 & 0.07415 \\
\hline$\hat{\theta}_{B}(12)$ & 0.06488 & $6.458 \mathrm{E}-4$ & 0.06363 & 0.06488 & 0.06616 \\
\hline$\hat{\theta}_{B}(15)$ & 0.06162 & 0.00144 & 0.05883 & 0.06161 & 0.06447 \\
\hline$\hat{\theta}_{B}(19)$ & 0.05991 & 0.001275 & 0.05746 & 0.05989 & 0.06242 \\
\hline$\hat{\theta}_{B}(3)$ & 0.05716 & $6.19 \mathrm{E}-4$ & 0.05595 & 0.05716 & 0.05837 \\
\hline$\hat{\theta}_{B}(14)$ & 0.05604 & 0.001421 & 0.0533 & 0.05602 & 0.0589 \\
\hline$\hat{\theta}_{B}(7)$ & 0.0546 & $5.093 \mathrm{E}-4$ & 0.05362 & 0.0546 & 0.05562 \\
\hline$\hat{\theta}_{B}(11)$ & 0.0513 & $7.08 \mathrm{E}-4$ & 0.04993 & 0.05129 & 0.05273 \\
\hline$\hat{\theta}_{B}(5)$ & 0.04843 & $5.16 \mathrm{E}-4$ & 0.04741 & 0.04843 & 0.04944 \\
\hline$\hat{\theta}_{B}(17)$ & 0.04678 & $9.27 \mathrm{E}-4$ & 0.04499 & 0.04677 & 0.04858 \\
\hline$\hat{\theta}_{B}(8)$ & 0.03896 & $4.613 \mathrm{E}-4$ & 0.03807 & 0.03895 & 0.03988 \\
\hline$\hat{\theta}_{B}(4)$ & 0.0377 & $6.396 \mathrm{E}-4$ & 0.03647 & 0.03769 & 0.03898 \\
\hline$\hat{\theta}_{B}(10)$ & 0.03607 & $7.565 \mathrm{E}-4$ & 0.0346 & 0.03606 & 0.03756 \\
\hline$\hat{\theta}_{B}(9)$ & 0.0154 & $3.49 \mathrm{E}-4$ & 0.01471 & 0.01539 & 0.01609 \\
\hline$\hat{\theta}_{B}(1)$ & 0.00407 & $3.258 \mathrm{E}-4$ & 0.00346 & 0.004059 & 0.004734 \\
\hline
\end{tabular}

Keterangan. Kabupaten/kota disimbolkan dengan nomor urut setiap daerah pada data Tabel 1 
Dari Tabel 2, dapat dilihat bahwa nilai tengah posterior yang mewakili penduga proporsi Bayes dari daerah ke-13 (Kota Padang) merupakan nilai tengah tertinggi, yaitu 0.1399 dengan selang kepercayaan 95\% dari penduga proporsi adalah [0.1388, 0.141]. Setelah Kota Padang, daerah yang memiliki proporsi pengangguran terbuka tertinggi adalah Kabupaten Pesisir Selatan (11.06\%), diikuti Kabupaten Padang Pariaman $(7.409 \%)$ hingga yang terakhir ditempati oleh Kepulauan Mentawai (0.407\%). Jadi, dapat disimpulkan bahwa proporsi pengangguran terbuka di Kota Padang adalah proporsi yang paling tinggi dibandingkan dengan kabupaten/kota lainnya di Sumatera Barat pada tahun 2013.

Sebaran penduga proporsi pengangguran terbuka di Sumatera Barat tahun 2013 juga ditampilkan pada plot Density posterior seperti berikut.
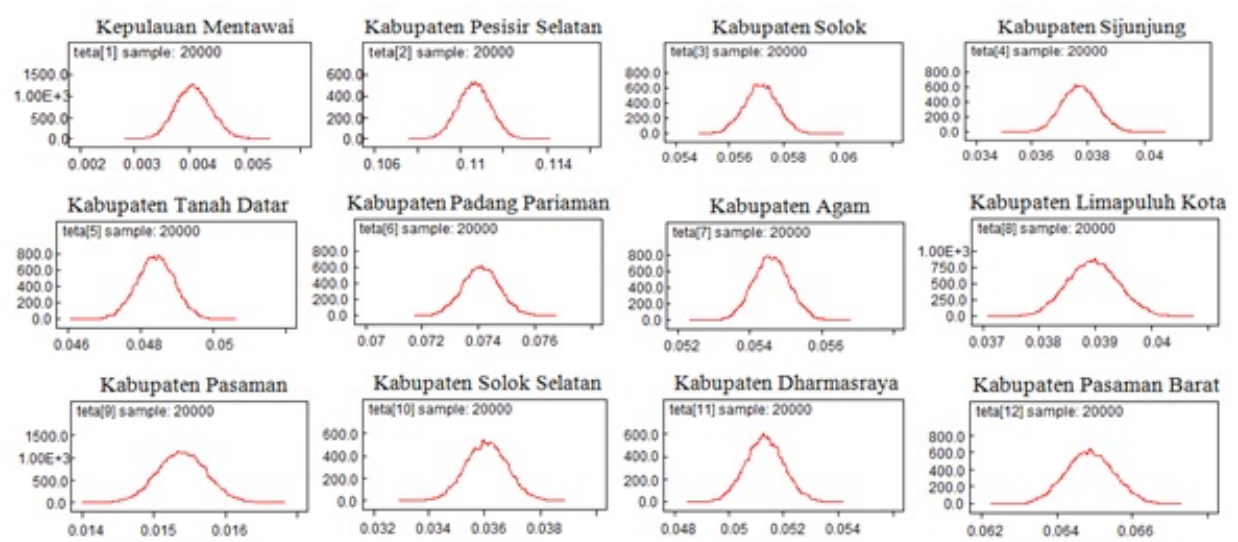

Kabupaten Solok Selatan
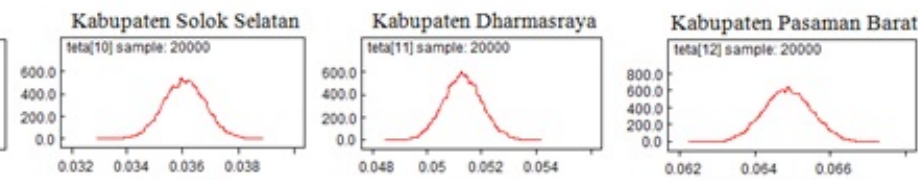

Kota Solok
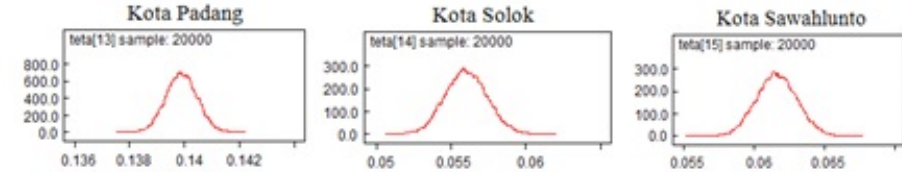

Kabupaten Pasaman Barat

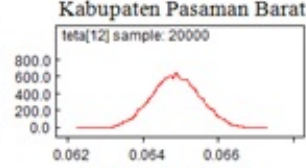

$0.062 \quad 0.064 \quad 0.066$

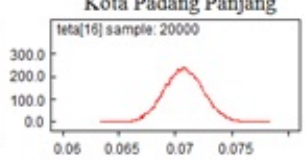

Kota Bukitting
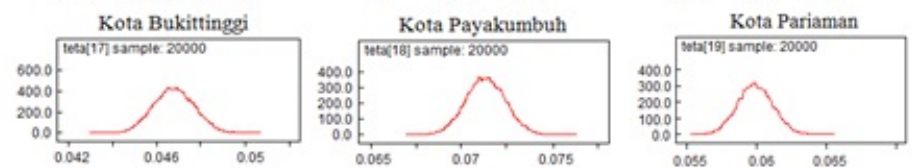

$0050065 \quad 007 \quad 0.075$

Gambar 1. Plot Density Posterior untuk Penduga Proporsi Pengangguran Terbuka setiap Kabupaten/Kota di Sumatera Barat tahun 2013

Plot density yang dihasilkan baik karena polanya cenderung halus dan memiliki pusat nilai tengah serta nilai batas atas dan bawah seperti nilai pada Tabel 2 sehingga plot density pada Gambar 1 juga menunjukkan nilai pendugaan selang untuk parameter $\theta$ dengan software WinBugs. Selain itu, Gambar 1 juga menunjukkan fungsi kepekatan peluang dari proporsi pengangguran terbuka yang menyebar secara normal.

Kemudian dilakukan pendugaan proporsi dengan situasi dimana jika seseorang yang termasuk pengangguran terbuka pada suatu daerah dapat berpindah dari satu 
daerah ke daerah lainnya di Sumatera Barat, maka diasumsikan bahwa proporsi pengangguran terbuka suatu saat akan sama di setiap daerah. Hasil yang diperoleh dengan menggunakan software WinBugs adalah

Tabel 3. Pendugaan Proporsi Pengangguran Terbuka di Sumatera Barat Tahun 2013 (diasumsikan proporsi setiap daerah suatu saat akan sama)

\begin{tabular}{|c|c|c|c|c|c|}
\hline$\hat{\theta}_{B}$ & $\begin{array}{c}\text { Nilai } \\
\text { Tengah }\end{array}$ & $\begin{array}{c}\text { Standar } \\
\text { Deviasi }\end{array}$ & $\begin{array}{c}\text { Batas Bawah } \\
2.5 \%\end{array}$ & Median & $\begin{array}{c}\text { Batas Atas } \\
97.5 \%\end{array}$ \\
\hline$\hat{\theta}_{B}(13)$ & 0.1399 & $5.77 \mathrm{E}-4$ & 0.1387 & 0.1399 & 0.141 \\
\hline$\hat{\theta}_{B}(2)$ & 0.1106 & $7.578 \mathrm{E}-4$ & 0.1092 & 0.1106 & 0.1121 \\
\hline$\hat{\theta}_{B}(6)$ & 0.07408 & $6.474 \mathrm{E}-4$ & 0.07283 & 0.07408 & 0.07538 \\
\hline$\hat{\theta}_{B}(18)$ & 0.07129 & 0.001098 & 0.06916 & 0.07129 & 0.07346 \\
\hline$\hat{\theta}_{B}(16)$ & 0.07067 & 0.001741 & 0.06733 & 0.07066 & 0.07408 \\
\hline$\hat{\theta}_{B}(12)$ & 0.06487 & $6.502 \mathrm{E}-4$ & 0.06361 & 0.06488 & 0.06615 \\
\hline$\hat{\theta}_{B}(15)$ & 0.06157 & 0.001465 & 0.05876 & 0.06157 & 0.06444 \\
\hline$\hat{\theta}_{B}(19)$ & 0.05987 & 0.0013 & 0.05736 & 0.05987 & 0.06246 \\
\hline$\hat{\theta}_{B}(3)$ & 0.05717 & $6.095 \mathrm{E}-4$ & 0.05599 & 0.05717 & 0.05836 \\
\hline$\hat{\theta}_{B}(14)$ & 0.05601 & 0.001436 & 0.05328 & 0.05599 & 0.05883 \\
\hline$\hat{\theta}_{B}(7)$ & 0.0546 & $5.1 \mathrm{E}-4$ & 0.0536 & 0.05461 & 0.0556 \\
\hline$\hat{\theta}_{B}(11)$ & 0.0513 & $7.16 \mathrm{E}-4$ & 0.04993 & 0.0513 & 0.0527 \\
\hline$\hat{\theta}_{B}(5)$ & 0.04842 & $5.2 \mathrm{E}-4$ & 0.04742 & 0.04842 & 0.04943 \\
\hline$\hat{\theta}_{B}(17)$ & 0.04676 & $9.378 \mathrm{E}-4$ & 0.04497 & 0.04675 & 0.0486 \\
\hline$\hat{\theta}_{B}(8)$ & 0.03896 & $4.639 \mathrm{E}-4$ & 0.03806 & 0.03896 & 0.03988 \\
\hline$\hat{\theta}_{B}(4)$ & 0.0377 & $6.406 \mathrm{E}-4$ & 0.03647 & 0.03769 & 0.03896 \\
\hline$\hat{\theta}_{B}(10)$ & 0.03606 & $7.661 \mathrm{E}-4$ & 0.03459 & 0.03605 & 0.03755 \\
\hline$\hat{\theta}_{B}(9)$ & 0.0154 & $3.549 \mathrm{E}-4$ & 0.01473 & 0.0154 & 0.01609 \\
\hline$\hat{\theta}_{B}(1)$ & 0.004156 & $3.94 \mathrm{E}-4$ & 0.003544 & 0.004146 & 0.00482 \\
\hline
\end{tabular}

Keterangan. Kabupaten/kota disimbolkan dengan nomor urut setiap daerah pada data Tabel 1.

Tabel 3 menunjukkan penduga proporsi $\theta$ yang diperoleh dari nilai tengah posteriornya dimana diasumsikan bahwa proporsi $\theta$ setiap kabupaten/kota di Sumatera Barat suatu saat akan sama. Ternyata hasil penduga proporsi pengangguran terbuka masing-masing daerah tidak mengalami perbedaan yang signifikan dengan penduga proporsi pengangguran terbuka pada Tabel 2.

Selanjutnya, hasil dari pendugaan proporsi pengangguran terbuka setiap kabupaten/kota di Sumatera Barat tahun 2013 dirangking dan ditampilkan dalam bentuk histogram seperti berikut.

Dari histogram pada Gambar 2 dapat diketahui kabupaten/kota mana yang memiliki proporsi pengangguran terbuka tertinggi sampai terendah. Ranking pada histogram menunjukkan tinggi rendahnya nilai penduga proporsi dari masingmasing kabupaten/kota [7], misalnya ranking 1 yang ditempati oleh Kepulauan 

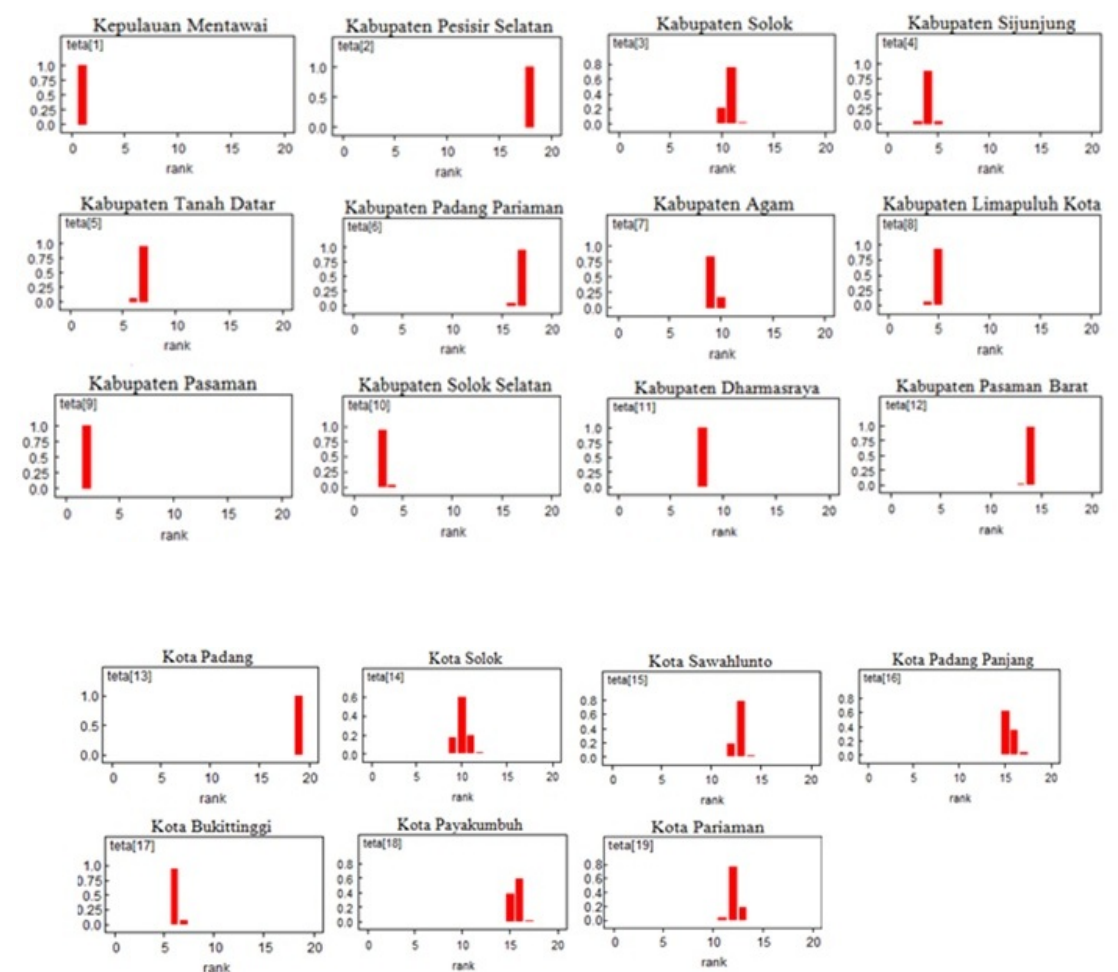

Gambar 2. Histogram Rank dari Kabupaten/Kota di Sumatera Barat tahun 2013 berdasarkan Nilai Penduga Proporsi Pengangguran Terbuka

Mentawai. Hal ini berarti Kepulauan Mentawai memiliki nilai penduga proporsi pengangguran terbuka yang paling rendah dan berlaku seterusnya untuk kabupaten/kota lainnya.

Selain menunjukkan ranking kabupaten/kota berdasarkan nilai penduga proporsi, histogram pada Gambar 2 menunjukkan besar peluang ranking yang dimiliki oleh masing-masing kabupaten/kota, seperti Kepulauan Mentawai berada pada ranking 1, Kabupaten Pesisir Selatan di ranking 18, Kabupaten Pasaman di ranking 2, Kabupaten Dharmasraya di ranking 8 dan Kota Padang di ranking 19. Kelima daerah tersebut memiliki peluang sebesar 1 dan empat belas daerah lainnya memiliki peluang kurang dari 1 untuk berada di rangking masing-masing. Kabupaten/kota yang rankingnya berpeluang 1 memiliki selang nilai penduga proporsi yang tidak berpartisi dengan selang nilai penduga proporsi daerah lainnya dalam 20.000 kali iterasi. Peluang ranking masing-masing kabupaten/kota yang telah diurutkan dari selang nilai proporsi terkecil hingga terbesar dapat juga dapat ditunjukkan pada gambar berikut.

Dari Gambar 3 dapat dibuktikan bahwa Kepulauan Mentawai, Kabupaten Pesisir Selatan, Kabupaten Pasaman, Kabupaten Dharmasraya dan Kota Padang memiliki peluang sebesar 1 untuk berada di ranking masing-masing sesuai hasil Tabel 3 dan Gambar 2. Hal ini terlihat dari garis yang terbentuk untuk mewakili 


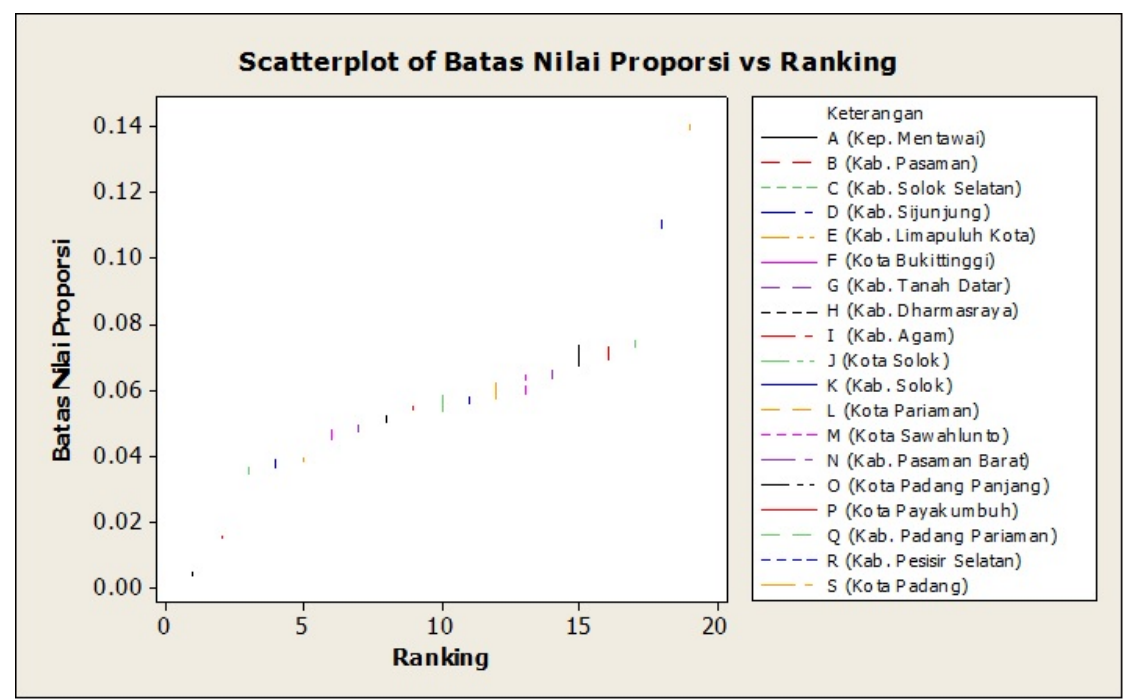

Gambar 3. Scatterplot Peranking Proporsi Pengangguran Terbuka setiap Kabupaten/Kota di Sumatera Barat Tahun 2013

kabupaten/kota tersebut tidak menyinggung garis dari daerah lainnya.

\section{Kesimpulan}

Pendugaan parameter proporsi pengangguran terbuka dapat ditentukan dalam bentuk perangkingan yang didasari oleh nilai pendugaan proporsi pengangguran terbuka dengan metode Bayes pada masing-masing kabupaten/kota di Provinsi Sumatera Barat tahun 2013 dalam selang tertentu yang berurutan. Proses perankingan memenuhi asumsi bahwa proporsi pengangguran terbuka yang diduga dengan metode Bayes menyebar pada distribusi Beta. Dari hasil perankingan diperoleh proporsi pengangguran terbuka di Kepulauan Mentawai menempati ranking pertama dan Kota Padang pada ranking ke-19. Kondisi ini diharapkan dapat membantu pemerintah untuk dapat lebih mengkonsentrasikan perhatian di bidang kependudukan dan ketenagakerjaan pada daerah-daerah yang memiliki ranking pengangguran terbuka yang tinggi sehingga proporsi pengangguran terbuka dapat ditekan secara maksimal.

\section{Daftar Pustaka}

[1] Bain, L. J and Engelhardt, M. 1992. Introduction to Probability and Mathematical Statistics Second Edition. California: Duxbury Press.

[2] Berger, C. 1990. Statistical Inference. New York: Pasific Grove.

[3] BPS. 2014. Keadaan Angkatan Kerja di Indonesia Agustus 2014. Jakarta: Badan Pusat Statistik.

[4] BPS. 2013. Keadaan Angkatan Kerja di Sumatera Barat Agustus 2013. Padang: Badan Pusat Statistik. 
74 Tiara Shofi Edriani dkk.

[5] Bolstad, W. M. 2007. Introduction to Bayesian Statistics Second Edition. Amerika: A John Wiley \& Sons, Inc.

[6] Box, G. E. P and Tiao, G. C. 1973. Bayesian Inference in Statical Analysis. Philippines: Addision-Wesley Publishing Company, Inc.

[7] Ntzoufras, I. 2009. Bayesian Modelling Using WinBUGS. New Jersey: John Wiley \& Sons, Inc. 